\title{
Pediococcus argentinicus sp. nov. from Argentinean fermented wheat flour and identification of Pediococcus species by pheS, rpo $A$ and atp $A$ sequence analysis
}

\author{
Correspondence \\ Katrien De Bruyne \\ Katrien.DeBruyne@UGent.be
}

\author{
Katrien De Bruyne, ${ }^{1}$ Charles M. A. P. Franz, ${ }^{2}$ Marc Vancanneyt, ${ }^{3}$ \\ Ulrich Schillinger, ${ }^{2}$ Fernanda Mozzi, ${ }^{4}$ Graciela Font de Valdez, ${ }^{4}$ \\ Luc De Vuyst ${ }^{5}$ and Peter Vandamme ${ }^{1}$
}
${ }^{1}$ Laboratory of Microbiology, Ghent University, Ledeganckstraat 35, B-9000 Ghent, Belgium
${ }^{2}$ Federal Research Centre for Nutrition and Food, Institute of Hygiene and Toxicology, Haid-und- Neu-Strasse 9, D-76131 Karlsruhe, Germany
${ }^{3}$ BCCM/LMG Bacteria Collection, Ghent University, Ledeganckstraat 35, B-9000 Ghent, Belgium
${ }^{4}$ Centro de Referencia para Lactobacilos (CERELA)-CONICET, Chacabuco 145, 4000 San Miguel de Tucumán, Argentina
${ }^{5}$ Research Group of Industrial Microbiology and Food Biotechnology (IMDO), Department of Applied Biological Sciences and Engineering, Vrije Universiteit Brussel, Pleinlaan 2, B-1050 Brussels, Belgium

\begin{abstract}
A Gram-positive, small coccus-shaped lactic acid bacterium, strain LMG $23999^{\top}$, was isolated from Argentinean wheat flour. 16S rRNA gene sequence analysis revealed that the phylogenetic position of the novel strain was within the genus Pediococcus, with Pediococcus stilesii, Pediococcus pentosaceus and Pediococcus acidilactici as its closest relatives (97.7, 97.3 and $96.9 \%$ gene sequence similarity, respectively). Fluorescent amplified fragment length polymorphism fingerprinting of whole genomes and whole-cell protein electrophoresis confirmed the unique taxonomic status of the novel strain. DNA-DNA hybridizations, DNA G $+\mathrm{C}$ content determination, comparative sequence analysis of the pheS, rpoA and atp $A$ genes and physiological and biochemical characterization demonstrated that strain LMG $23999^{\top}$ (=CCUG $54535^{\top}=\mathrm{CRL} 776^{\top}$ ) represents a novel species for which the name Pediococcus argentinicus sp. nov. is proposed. Multi-locus sequence analysis based on pheS, rpoA and atp $A$ genes was found to be a suitable method for the identification of species of the genus Pediococcus.
\end{abstract}

Pediococci are homolactic acid-fermentative, non-motile, catalase-negative, facultative anaerobes of the family Lactobacillaceae. They inhabit fermentable-sugar-rich niches such as plant materials and fermented foods.

\footnotetext{
Abbreviations: FAFLP, fluorescent amplified fragment length polymorphism; LAB, lactic acid bacteria; $T_{O R}$, temperature of optimal renaturation.

The GenBank/EMBL/DDBJ accession number for the $16 \mathrm{~S}$ rRNA gene sequence of LMG $23999^{\top}$ is AM709786. The accession numbers for the pheS, rpoA and atpA gene sequences reported in this paper are AM899805-AM899946, as indicated in Supplementary Fig. S2a-c.

Supplementary figures showing a cluster analysis of whole cell protein profiles with a UPGMA dendrogram and additional neighbour-joining phylogenetic trees based on pheS, rpoA and atp $A$ gene sequences are available with the online version of this paper. A supplementary table giving details of the genomes used for the design of primers rpo-21- $\mathrm{F}^{\star}$ and rpoA-23- $\mathrm{R}^{*}$ is also provided.
}

Strains of the genus Pediococcus are used in the food industry as starter cultures for fermented meat or fish products and dairy products (Leroy \& De Vuyst, 2004; Simpson \& Taguchi, 1995). However, quality problems in beer and wine due to pediococci have also been reported (Renouf et al., 2007; Sakamoto \& Konings, 2003). In the present study, we describe a novel species of the genus Pediococcus isolated from Argentinean fermented wheat flour. Despite their importance for the food industry, the correct identification of Pediococcus strains is complicated by their ambiguous response in traditional physiological tests and methods. Nowadays, speciation is based on habitat, DNA-DNA hybridizations and tolerance of temperature, $\mathrm{pH}$ and $\mathrm{NaCl}$ (Dobson et al., 2002; Garvie, 1974, 1986). In this study, sequence analysis of the genes encoding the alpha subunits of phenylalanyl-tRNA synthase (pheS), RNA polymerase ( $r p o A)$ and ATP synthase 
$(\operatorname{atp} A)$ was developed as an alternative approach for the identification of species of the genus Pediococcus. Special attention was give to Pediococcus dextrinicus as it represents a distantly related species. Konstantinidis et al. (2006) considered that three was the minimum number of genes needed for multilocus, sequence-based differentiation between species. This number of genes is required in order to exclude possible horizontal gene transfer or recombination events. The three genes used in this study have already given satisfactory results with several genera of lactic acid bacteria (De Bruyne et al., 2007; Naser et al., 2005a, b, 2007).

Strain LMG $23999^{\mathrm{T}}\left(=\mathrm{CRL} 776^{\mathrm{T}}\right)$ was isolated in 1990 in the Centro de Referencia para Lactobacilos (CERELA, CONICET), San Miguel de Tucumán, Argentina. Wheat flour was mixed with warm sterilized tap water and after a fermentation of 4-6 days at $30{ }^{\circ} \mathrm{C}$, samples of the dough were taken. Samples were diluted to $10^{-6}$ in peptone water $(0.1 \% \mathrm{w} / \mathrm{v})$ and plated onto LAPTg agar using the pour plate technique. Plates were incubated aerobically at $37^{\circ} \mathrm{C}$ for $48 \mathrm{~h}$. The strain was subcultured onto MRS agar at $37^{\circ} \mathrm{C}$, unless indicated otherwise.

The phylogenetic position of strain LMG $23999^{\mathrm{T}}$ was first determined by analysis of its $16 \mathrm{~S}$ rRNA gene sequence, as described by Vancanneyt et al. (2004) using the following modifications. The PCR-amplified 16S rRNA gene was purified by using a NucleoFast 96 PCR Clean-up kit (Macherey-Nagel). Sequencing reactions were purified using a Montage SEQ96 Sequencing Reaction Clean-up kit (Millipore). Electrophoresis of sequence reaction products was performed by using an ABI Prism 3100 Genetic Analyzer (Applied Biosystems). FASTA analysis of the 16S rRNA gene sequence of strain LMG $23999^{\mathrm{T}}$ (a continuous stretch of $1492 \mathrm{bp}$ ) revealed that Pediococcus stilesii, Pediococcus pentosaceus and Pediococcus acidilactici were the closest relatives (with 97.7, 97.3 and 96.9\% sequence similarity, respectively). The $16 \mathrm{~S}$ rRNA gene sequence of strain LMG $23999^{\mathrm{T}}$ and sequences of reference strains (retrieved from EMBL) were aligned using CLUSTAL_X. A neighbour-joining phylogenetic tree was constructed using the BioNumerics software package, version 4.61 (Applied Maths). The statistical reliability of the tree topology was evaluated by bootstrapping analysis (Fig. 1). The phylogenetic tree of the genus Pediococcus consisted of two separate clades. The clade containing strain LMG $23999^{\mathrm{T}}$ also included Pediococcus claussenii, $P$. stilesii, $P$. acidilactici and $P$. pentosaceus. The second clade comprised Pediococcus ethanolidurans, Pediococcus siamensis, Pediococcus cellicola, Pediococcus damnosus, Pediococcus inopinatus and Pediococcus parvulus. The species $P$. dextrinicus represented a divergent line which was not surprising as this species is atypical of the genus Pediococcus and it has been suggested that $P$. dextrinicus may represent a novel genus (Holzapfel et al., 2005).

SDS-PAGE of whole-cell proteins and fluorescent amplified fragment length polymorphism (FAFLP) analysis were used to compare strain LMG $23999^{\mathrm{T}}$ with other strains of the genus Pediococcus, especially strains belonging to its nearest phylogenetic neighbours $P$. stilesii, $P$. pentosaceus and $P$. acidilactici. The protein profiles of all reference strains used were from a previous study (Franz et al., 2006). SDS-PAGE of cellular proteins from strain LMG $23999^{\mathrm{T}}$ was performed as described by Pot et al. (1994). Densitometric analysis, normalization and interpolation of protein profiles and numerical analysis were performed by the use of BioNumerics software package, version 4.61 (Applied Maths). When compared with those of the Pediococcus reference strains, the whole-cell protein profile of strain LMG $23999^{\mathrm{T}}$ was well separated from P. stilesii, $P$. pentosaceus and $P$. acidilactici, its nearest phylogenetic

\footnotetext{
$\underline{1 \%}$

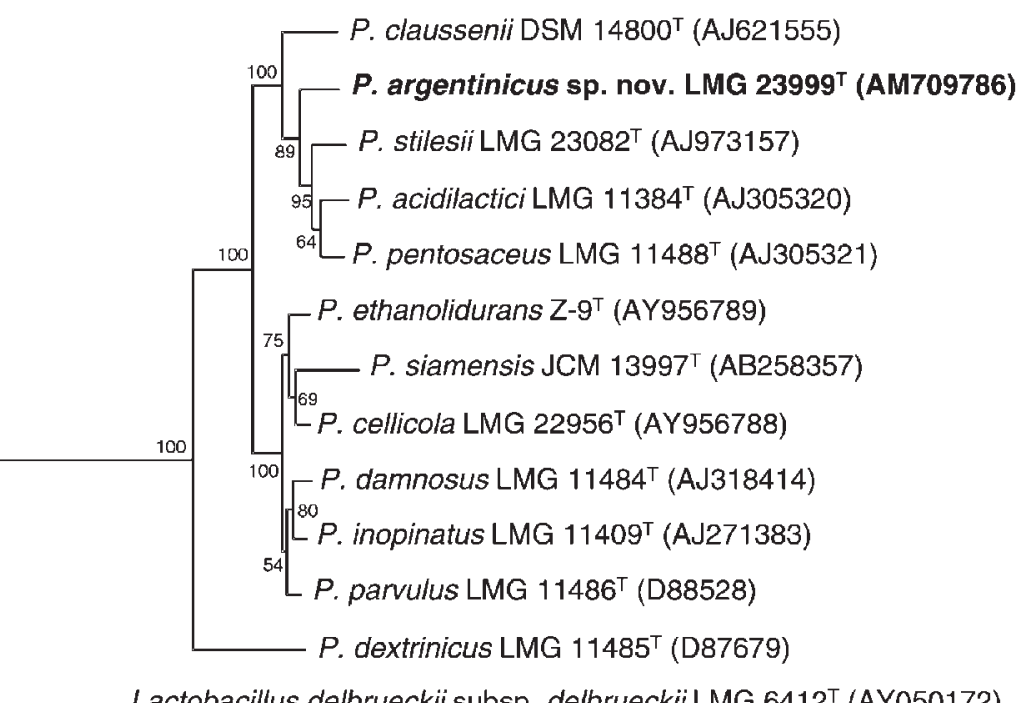

Fig. 1. Phylogenetic neighbour-joining tree based on 16S rRNA gene sequence analysis showing the phylogenetic relationships of Pediococcus argentinicus sp. nov. LMG $23999^{\top}$ within the genus Pediococcus. Lactobacillus delbrueckii subsp. delbrueckii LMG $6412^{\top}$ was used as the outgroup organism. Bootstrap percentage values (>50) based on 500 tree replications are indicated at the branching points. Bar, 1\% sequence divergence.
} 
neighbours (see Supplementary Fig. S1, available in IJSEM Online). The unique position of strain LMG $23999^{\mathrm{T}}$ was confirmed by FAFLP analysis. Already available FAFLP fingerprint patterns of Pediococcus reference strains were used (Franz et al., 2006) and additional patterns for $P$. ethanolidurans, $P$. siamensis and $P$. argentinicus were generated as described by Franz et al. (2006). The resulting electrophoretic patterns were tracked and normalized using the GENESCAN 3.1 software package (Applera). Normalized tables of peaks were transferred into the BioNumerics software package, version 4.61 (Applied Maths). The FAFLP fingerprint of strain LMG $23999^{\mathrm{T}}$ was compared with reference profiles of its closest phylogenetic neighbours and with those of the type strains of all recognized species within the genus Pediococcus (Fig. 2). The results confirmed that strain LMG $23999^{\mathrm{T}}$ was very different from its nearest neighbours and from other recognized species of the genus Pediococcus.

Genomic DNA of strain LMG $23999^{\mathrm{T}}$ and of P. stilesii LMG $23082^{\mathrm{T}}, P$. pentosaceus LMG $11488^{\mathrm{T}}$ and $P$. acidilactici LMG $11384^{\mathrm{T}}$ was isolated according to Marmur (1961), as modified by Stackebrandt \& Kandler (1979). DNA-DNA hybridizations were performed using the spectrophotometric method as described by De Ley et al. (1970). Hybridization values of strain LMG $23999^{\mathrm{T}}$ towards strains LMG $23082^{\mathrm{T}}$ [ $\mathrm{T}_{\mathrm{OR}}$ (temperature of optimal renaturation): $68.4{ }^{\circ} \mathrm{C}$, LMG $11488^{\mathrm{T}}\left(\mathrm{T}_{\mathrm{OR}}: 67.8^{\circ} \mathrm{C}\right)$ and LMG $11384^{\mathrm{T}}$ $\left(\mathrm{T}_{\mathrm{OR}}: 69.7^{\circ} \mathrm{C}\right.$ ) were 24,25 and $21 \%$, respectively, confirming that strain LMG $23999^{\mathrm{T}}$ represents a novel species (Wayne et al., 1987). The DNA G + C content of strain LMG $23999^{\mathrm{T}}$ was determined as described by
Mesbah et al. (1989) using a Waters Breeze HPLC system and XBridge Shield RP18 column. The solvent used was $0.02 \mathrm{M} \mathrm{NH} \mathrm{NH}_{4} \mathrm{H}_{2} \mathrm{PO}_{4}$ ( $\left.\mathrm{pH} 4.0\right), \quad 1.5 \%$ (v/v) acetonitrile. Non-methylated lambda phage (Sigma) and Escherichia coli LMG 2093 DNA were used as the calibration reference and control, respectively. The DNA G + C content of strain LMG $23999^{\mathrm{T}}$ was $40.8 \mathrm{~mol} \%$. This value was consistent with the DNA $\mathrm{G}+\mathrm{C}$ contents observed in the genus Pediococcus, which are 37-42 mol\% (Dobson et al., 2002; Liu et al., 2006; Sneath et al., 1986; Tanasupawat et al., 2007; Zhang et al., 2005).

As already investigated for the genera Lactobacillus (Naser et al., 2007), Enterococcus (Naser et al., 2005a, b) and Leuconostoc (De Bruyne et al., 2007), we evaluated whether pheS, rpoA and atpA gene sequence analysis could be used to differentiate species of the genus Pediococcus. In order to assess inter- and intra-species variability among the loci, a total of 44 Pediococcus strains was examined: 18 reference strains and 26 field isolates which were additionally identified through AFLP and SDS-PAGE of whole-cell proteins. Several representative strains per species were included when possible. Bacterial strains, depositors and sources are listed in Table 1. The design of the primers, amplification conditions and sequencing reactions were as described by Naser et al. (2005a, b). The primer combinations pheS-21-F/pheS-23-R, rpoA-21-F/rpoA-23$\mathrm{R}$ and atpA-20-F/atpA-26-R amplified the target genes of most strains. When no amplification product for the atpA gene was obtained, an alternative primer set atpA-22-F/ atpA-26-R was used. For the amplification of the $r p o A$ genes of $P$. pentosaceus strains LMG 13561, LMG 13562,

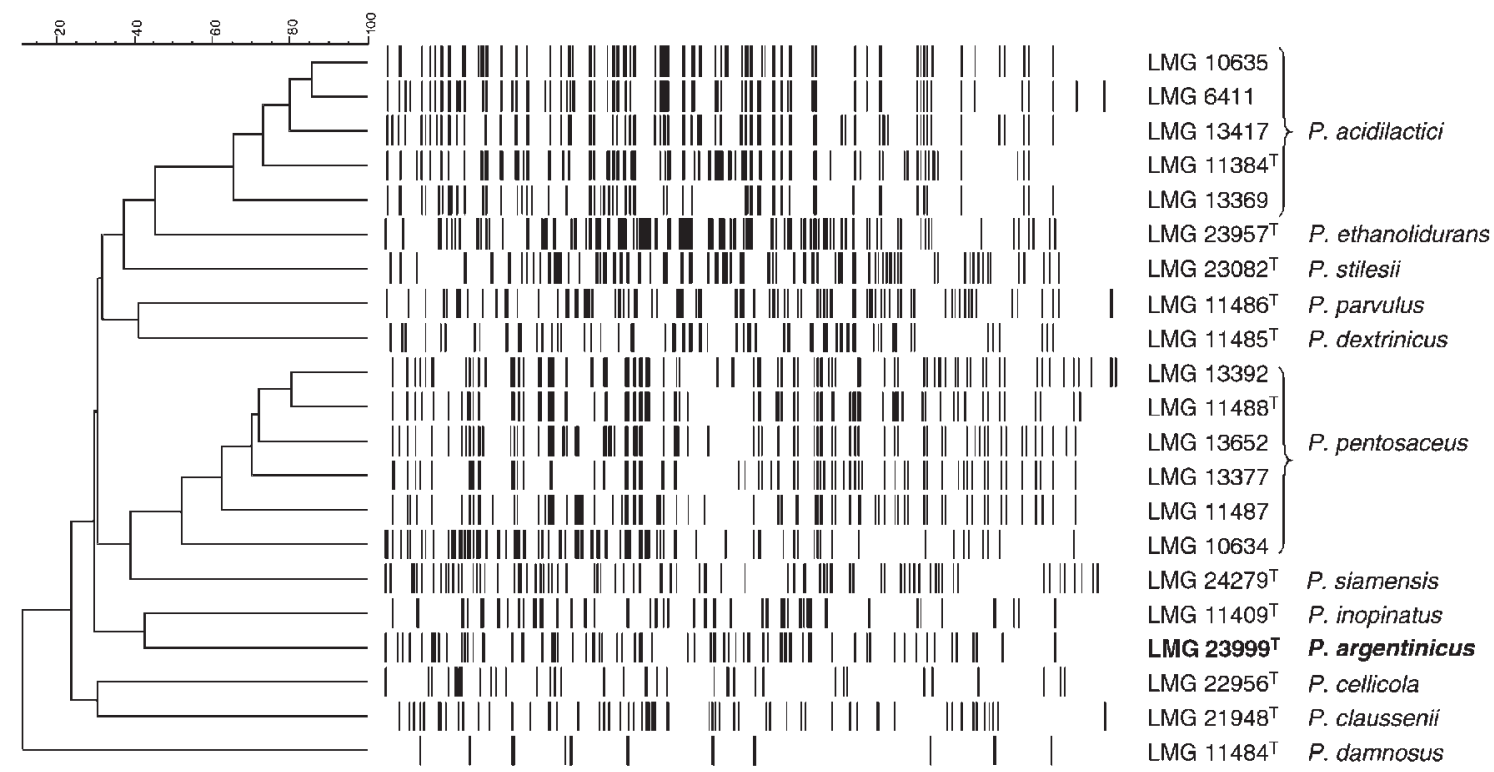

Fig. 2. FAFLP patterns and dendrogram based on the UPGMA linkage of Dice coefficients (expressed as percentage values for convenience) of Pediococcus argentinicus sp. nov. LMG $23999^{\top}$ and of reference strains of all recognized species of the genus Pediococcus. 
Table 1. List of Pediococcus strains used in this study

\begin{tabular}{|c|c|c|}
\hline Strains & Depositor ${ }^{*}$ & Source \\
\hline \multicolumn{3}{|l|}{ P. argentinicus } \\
\hline LMG $23999^{\mathrm{T}}$ & Own isolate & Commercial wheat flour (1990, Argentina) \\
\hline \multicolumn{3}{|l|}{ P. acidilactici } \\
\hline LMG 6411 & DSMZ & Not known \\
\hline LMG 10635 & A. Ledeboer & Plant \\
\hline LMG $11384^{\mathrm{T}}$ & Rijkszuivelstation, Melle & Barley \\
\hline LMG 13362 & NV Radar, Deinze & Grass sample (Belgium) \\
\hline LMG 13369 & NV Radar, Deinze & Grass sample (Belgium) \\
\hline LMG 17680 & G. Rusul & Chili bo (Malaysia) \\
\hline \multicolumn{3}{|l|}{ P. cellicola } \\
\hline LMG $22956^{\mathrm{T}}$ & CGMCC & Distilled-spirit-fermenting cellar wall (2004, China) \\
\hline \multicolumn{3}{|l|}{ P. claussenii } \\
\hline LMG $21948^{\mathrm{T}}$ & DSMZ & Spoiled beer (Canada) \\
\hline LAB 990 & Heineken & Beer (1994, The Netherlands) \\
\hline LAB 994 & Heineken & Beer (1994, The Netherlands) \\
\hline LAB 1004 & Heineken & Beer (1994, The Netherlands) \\
\hline LAB 1014 & Heineken & Beer (1994, The Netherlands) \\
\hline LAB 1231 & Heineken & Beer (1994, The Netherlands) \\
\hline LAB 1232 & Heineken & Beer (1994, The Netherlands) \\
\hline LAB 1329 & Heineken & Beer (1994, The Netherlands) \\
\hline \multicolumn{3}{|l|}{ P. damnosus } \\
\hline LMG $11484^{\mathrm{T}}$ & NCFB & Lager beer yeast \\
\hline LAB 1330 & Heineken & Beer (1994, Belgium) \\
\hline LAB 1362 & W. Simpson & Not known \\
\hline LAB 1449 & I. Bohack & Not known \\
\hline \multicolumn{3}{|l|}{ P. dextrinicus } \\
\hline LMG $11485^{\mathrm{T}}$ & NCFB & Silage \\
\hline \multicolumn{3}{|l|}{ P. ethanolidurans } \\
\hline LMG $23957^{\mathrm{T}}$ & CGMCC & Distilled-spirit-fermenting cellar wall (2004, China) \\
\hline LMG 13386 & NV Radar, Deinze & Grass sample (Belgium) \\
\hline LMG 13387 & NV Radar, Deinze & Grass sample (Belgium) \\
\hline \multicolumn{3}{|l|}{ P. inopinatus } \\
\hline LMG $11409^{\mathrm{T}}$ & DSMZ & Brewery yeast \\
\hline LMG 11410 & DSMZ & Beer \\
\hline LMG 22104 & J. Leisner & Beer (Czech Republic) \\
\hline LMG 22105 & J. Leisner & Beer (Czech Republic) \\
\hline LAB 1451 & I. Bohack & Not known \\
\hline LAB 1454 & I. Bohack & Not known \\
\hline \multicolumn{3}{|l|}{ P. parvulus } \\
\hline LMG $11486^{\mathrm{T}}$ & NCFB & Silage \\
\hline LMG 16740 & ATCC & Wine (Australia) \\
\hline LAB 194 & R. Vogel & Wine \\
\hline \multicolumn{3}{|l|}{ P. pentosaceus } \\
\hline LMG 10634 & Unilever, Vlaardingen & Fermented milk \\
\hline LMG $11488^{\mathrm{T}}$ & NCFB & Dried American beer yeast (1931) \\
\hline LMG 13392 & NV Radar, Deinze & Grass sample (Belgium) \\
\hline LMG 13561 & TNO-Voeding, Zeist & Not known \\
\hline LMG 13562 & TNO-Voeding, Zeist & Not known \\
\hline LMG 13652 & L. A. Devriese & Cat (Belgium) \\
\hline LMG 13377 & NV Radar, Deinze & Grass sample (Belgium) \\
\hline LMG 17236 & L. A. Devriese & Sow (Belgium) \\
\hline LMG 17237 & L. A. Devriese & Sow (Belgium) \\
\hline \multicolumn{3}{|l|}{ P. siamensis } \\
\hline LMG $24279^{\mathrm{T}}$ & $\mathrm{JCM}$ & Fermented tea leaves (2007, Thailand) \\
\hline \multicolumn{3}{|l|}{ P. stilesii } \\
\hline LMG $23082^{\mathrm{T}}$ & W. Holzapfel & White maize grains (1997, Nigeria) \\
\hline
\end{tabular}


Table 1. cont.

*ATCC, American Type Culture Collection; I. Bohack, Lehrstuhl für Technologie der Brauerei I, Technische Universität München, Germany; CGMCC, China General Microbiological Culture Collection Centre; L. A. Devriese, Ghent University, Ghent, Belgium; DSMZ, Deutsche Sammlung von Mikroorganismen und Zellkulturen; W. Holzapfel, Institute of Hygiene and Toxicology, Karlsruhe, Germany; JCM, Japan Collection of Microorganisms; A. Ledeboer, Unilever, Vlaardingen, The Netherlands; J. Leisner, Royal Veterinary and Agricultural University, Frederiksberg Copenhagen, Denmark; LMG, Belgian Co-ordinated Collections/Laboratory of Microbiology Ghent, Ghent, Belgium; NCFB, National Collection of Food Bacteria (now NCIMB); NCIMB, National Collections of Industrial, Food and Marine Bacteria, Aberdeen, UK; G. Rusul, University Putra, Malaysia; W. Simpson, BRF International, Surrey, UK; R. Vogel, Universität Hohenheim, Stuttgart, Germany.

LMG $11488^{\mathrm{T}}$, LMG 13377 and LMG 17237 and $P$. stilesii LMG $23082^{\mathrm{T}}$, no amplicon was obtained despite using different sets of primers and amplification conditions as described by Naser et al. (2005b). The objective of identifying a maximum number of lactic acid bacteria (LAB) strains using the same amplification protocol (Naser et al., 2005a, b) has led to the use of a standard protocol, which is probably not the most optimal protocol for some members of the genus Pediococcus. Failure due to DNA sequence variability in these genes, which prevented annealing of the PCR primers to their target sequences, was solved by designing new primers. The primers rpoA21-F and rpoA-23-R were evaluated against 53 LAB genomes (see Supplementary Table S1 in IJSEM Online) containing 32 Streptococcus strains, 12 Lactobacillus strains, three Lactococcus strains, two Enterococcus strains, two Oenococcus strains and one strain of Leuconostoc mesenteroides subsp. mesenteroides and, most important for the present study, P. pentosaceus ATCC 25745 (GenBank accession no. CP000422). The evaluation was performed using the genomic BLAST tool of NCBI (http://www. ncbi.nlm.nih.gov/sutils/genom_table.cgi). Starting from the rpoA amino acid sequence of Leuconostoc mesenteroides subsp. mesenteroides LMG $6893^{\mathrm{T}}$ translated from the gene sequence GenBank accession no. AM711294, a BLASTP sequence similarity search was performed against protein databases of genomes of all the members of the order Lactobacillales present in the database at time of writing (strain information and accession numbers are listed in Supplementary Table S1). The rpoA gene identities obtained were used to retrieve the rpoA nucleotide sequences from the whole genomes. Together with the primer sequences, all rpoA gene sequences were used to perform sequence alignments using CLUSTAL_X. The position of primers within the alignment was verified and substitutions were checked manually. An A/G substitution specific for the Pediococcus strains could be found in primer sequence rpoA-21-F and a T/A and a C/G substitution were found in primer sequence rpoA-23-R. Taking into account these substitutions and the information from the other $52 \mathrm{LAB}$ genomes, primers rpoA-21-F and rpoA-23-R were modified to rpoA-21-F $\mathrm{F}^{*}\left(5^{\prime}-\right.$ ATGATYGARTTTGARAARCC- $\left.3^{\prime}\right)$ and rpoA-23-R ${ }^{*}\left(5^{\prime}-\right.$ ACHSTRTTRATACCDGCNCG- $\left.3^{\prime}\right)$. Using these modified primers, $r p o A$ products for all the remaining strains were obtained.
The phylogenetic trees constructed for the pheS, rpoA and atp $A$ gene sequences are based on the neighbour-joining method and were obtained by importing the external sequence alignments from CLUSTAL_X into the BioNumerics software package. For each of the genes, the intra-species diversity was smaller than the inter-species diversity and, therefore, numerical analysis yielded species-specific clusters (see Supplementary Figs S2a-c in IJSEM Online). The topologies of the neighbour-joining phylogenetic trees roughly resembled those of the $16 \mathrm{~S}$ rRNA gene-based phylogeny. To resolve the ambiguous position of $P$. dextrinicus, for which suggestions for it to be reclassified next to the Lactobacillus casei group have already been made (Collins et al., 1990, 1991; Stiles \& Holzapfel, 1997), sequence data of the type strains of all species of the Lactobacillus casei group were included in the sequence analyses (Fig. 3, Supplementary Fig. S2a-c). P. dextrinicus represented the most divergent lineage in each of the analyses. This observation strongly supported the two options already suggested in the literature: to transfer $P$. dextrinicus to a new genus (Holzapfel et al., 2005) or to reclassify this species as a novel species of the genus Lactobacillus, close to the Lactobacillus casei group (Collins et al., 1990, 1991; Stiles \& Holzapfel, 1997). To date, no official proposal has been made for this change (Dobson et al., 2002). For the remaining pediococci species, both rpoA and $\operatorname{atp} A$ gene analysis yielded the same division into two clades, corresponding to the $16 \mathrm{~S}$ rRNA gene sequence phylogeny. Analysis of the pheS gene showed a slightly different topology; it was however the most discriminatory gene for the identification of species of the genus Pediococcus. By integrating information from different molecular markers, the simultaneous use of several housekeeping genes offers a higher reliability for bacterial identification (Fig. 3) (Konstantinidis et al., 2006). Using the concatenated gene sequences, all Pediococcus isolates could be classified into species-specific clusters. In addition, two previously unidentified Pediococcus isolates from grass silage in Belgium were identified as $P$. ethanolidurans in this study (Fig. 3), an observation that was confirmed by AFLP analysis and SDS-PAGE of wholecell proteins.

Morphological, physiological and biochemical tests were performed according to Schillinger \& Lücke (1987). Lactate enantiomer production was determined using an enzymic test kit (Roche Diagnostics). After $48 \mathrm{~h}$ growth, culture 


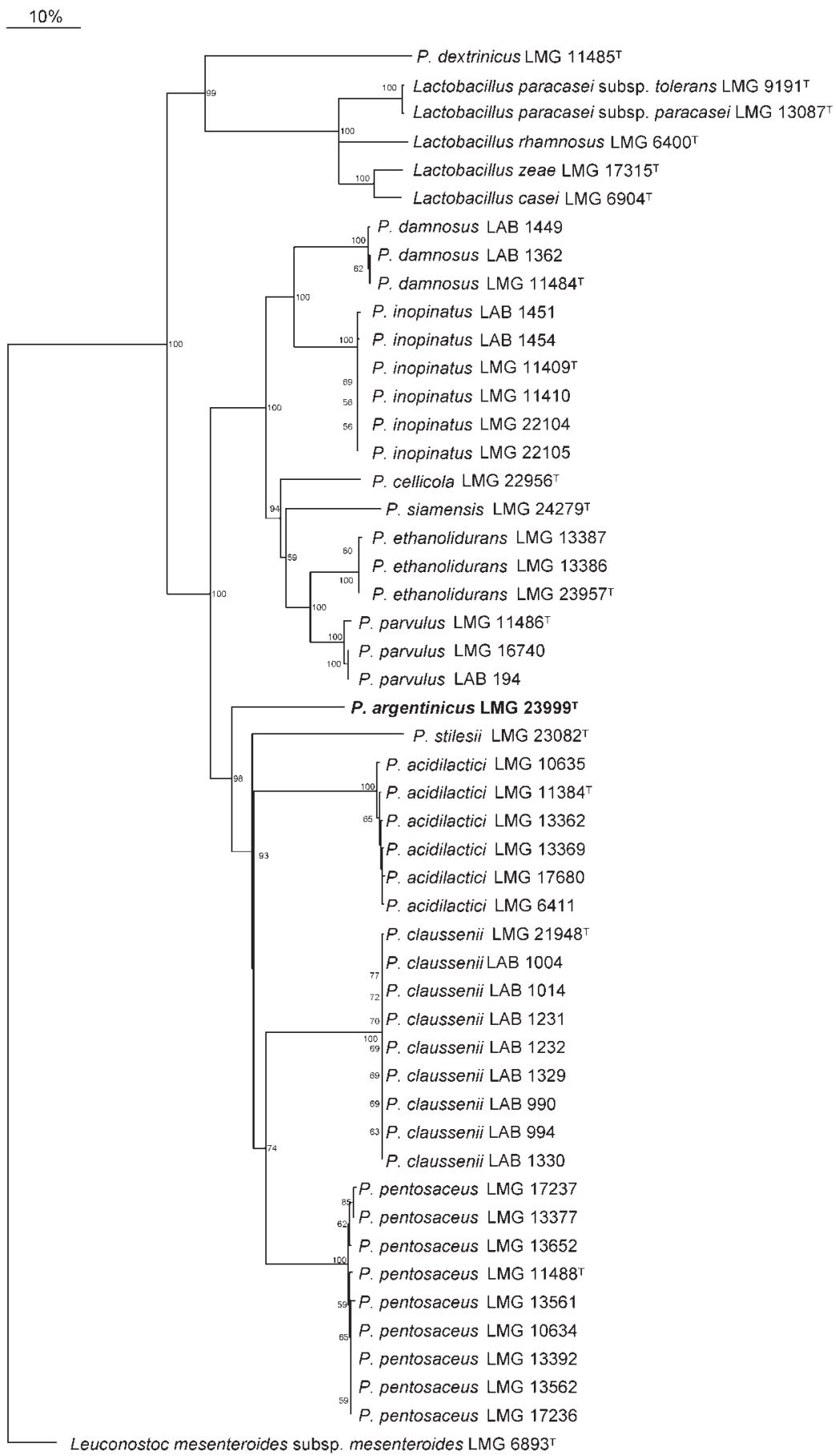

Fig. 3. Concatenated tree based on pheS (see Supplementary Fig. S2a), rрoA (see Supplementary Fig. S2b) and atp $A$ (see Supplementary Fig. S2c) gene sequences of Pediococcus strains and the type strains of all species belonging to the Lactobacillus casei group. Bootstrap percentages (>50) after 500 simulations are shown. Leuconostoc mesenteroides subsp. mesenteroides LMG $6893^{\top}$ was included as the outgroup organism. Bar, $10 \%$ sequence divergence.

supernatants comprised more than $90 \%$ L-lactate. After a prolonged incubation of 4 days, a DL-lactate mixture was obtained (87.6\% L-lactate, $12.4 \%$ D-lactate). The API 50 CHL Lactobacillus identification system (bioMérieux) was used to determine the carbohydrate fermentation profile. Morphological and physiological characteristics are given in the species description. An overview of the physiological differences between the novel species and the most closely related species is presented in Table 2. It is evident from these summarized physiological data that strain LMG
$23999^{\mathrm{T}}$ can be distinguished from related species of the genus Pediococcus by a combination of acid production tests from sugars (arabinose, galactose, lactose, maltose, mannitol, methyl $\alpha$-D-mannopyranoside and xylose), $\mathrm{NaCl}$ tolerance tests and by the lactic acid configuration.

The results of the polyphasic analysis demonstrate that strain LMG $23999^{\mathrm{T}}$ represents a novel species within the genus Pediococcus, for which we propose the name Pediococcus argentinicus sp. nov. Sequence analysis of the 
Table 2. Phenotypic characteristics that differentiate Pediococcus argentinicus sp. nov. from the most closely related species of the genus Pediococcus

Taxa: 1, P. argentinicus sp. nov. LMG $23999^{\mathrm{T}} ; 2$, P. acidilactici; 3, P. pentosaceus; 4, P. claussenii; 5, P. stilesii LMG $23082^{\mathrm{T}}$.,$+ 90 \%$ or more strains positive;,$- 90 \%$ or more strains negative; $\mathrm{d}, 11-89 \%$ of strains positive; ND, not determined. Some data were taken from Simpson \& Taguchi (1995), Holzapfel et al. (2005) and Franz et al. (2006).

\begin{tabular}{|lccccc|}
\hline Characteristic & $\mathbf{1}$ & $\mathbf{2}$ & $\mathbf{3}$ & $\mathbf{4}$ & $\mathbf{5}$ \\
\hline Growth at & & & & & \\
$\mathrm{pH} 9.0$ & - & - & - & - & + \\
$40{ }^{\circ} \mathrm{C}$ & + & + & $\mathrm{d}$ & + & + \\
$45{ }^{\circ} \mathrm{C}$ & - & + & $\mathrm{d}$ & - & + \\
$48{ }^{\circ} \mathrm{C}$ & - & + & - & - & - \\
Lactic acid configuration & $\mathrm{L}(+)$ & $\mathrm{DL}$ & $\mathrm{DL}$ & $\mathrm{L}(+)$ & $\mathrm{DL}$ \\
Acid from: & & & & & \\
Arabinose & - & $\mathrm{d}$ & + & - & - \\
Galactose & + & + & + & - & + \\
Lactose & - & $\mathrm{d}$ & + & - & - \\
Maltose & + & - & + & $\mathrm{d}$ & + \\
Mannitol & + & - & - & $\mathrm{d}$ & - \\
Methyl $\alpha$-D-mannopyranoside & + & $\mathrm{ND}$ & $\mathrm{ND}$ & - & - \\
Xylose & - & + & $\mathrm{d}$ & - & - \\
Max. NaCl concentration for growth $(\% \mathrm{w} / \mathrm{v})$ & 6 & 10 & 10 & 5 & 8 \\
DNA G+C content (mol\%) & 40.8 & 42.0 & 38.0 & 40.5 & 38.0 \\
\hline
\end{tabular}

pheS, rpoA and atpA genes proved to be a valuable technique for the differentiation of recognized species of the genus Pediococcus.

\section{Description of Pediococcus argentinicus sp. nov.}

Pediococcus argentinicus (ar.gen'ti.ni.cus. N.L. masc. adj. argentinicus pertaining to Argentina).

After $24 \mathrm{~h}$ growth, cells are small cocci $(0.7-1.0 \mu \mathrm{m})$ and occur singly or in pairs. They are Gram-positive, do not form spores and no gliding motility is observed. Colonies are greyish white, opaque, smooth and circular with a convex elevation and an entire margin. Both D- and Llactate are produced as end products of glucose metabolism. Able to grow at $\mathrm{pH}$ values of $4-8$ and at temperatures up to $40{ }^{\circ} \mathrm{C}$. The maximum $\mathrm{NaCl}$ concentration for growth is $6 \%(\mathrm{w} / \mathrm{v})$. Acid is produced from glucose, ribose, galactose, fructose, mannose, mannitol, methyl $\alpha$-D-mannopyranoside, $N$-acetylglucosamine, amygdalin, arbutin, aesculin, salicin, cellobiose, maltose, sucrose, gentiobiose and tagatose. Acid is not produced from glycerol, erythritol, D-arabinose, L-arabinose, D-xylose, L-xylose, adonitol, methyl $\beta$-D-xylopyranoside, sorbose, rhamnose, dulcitol, inositol, sorbitol, methyl $\alpha$-D-glucopyranoside, lactose, melibiose, trehalose, inulin, melezitose, raffinose, glycogen, xylitol, turanose, lyxose, D-fucose, L-fucose, Darabitol, L-arabitol, potassium gluconate, potassium 2ketogluconate or potassium 5-ketogluconate.

The type strain, LMG $23999^{\mathrm{T}}\left(=\mathrm{CCUG} 54535^{\mathrm{T}}=\mathrm{CRL} 776^{\mathrm{T}}\right.$ ), was isolated from Argentinean fermented wheat flour. The DNA G $+\mathrm{C}$ content of the type strain is $40.8 \mathrm{~mol} \%$.

\section{Acknowledgements}

This work was supported by the Federal Research Policy (Action for the promotion of and Cooperation with the Belgian Coordinated Collections of Microorganisms, contract C3/00/17), the bilateral scientific cooperation project between SECyT Argentina and FWOFlanders (project FW/PA/02-BIX/011) and the academic cooperation agreement between the Vrije Universiteit Brussel and CONICET. We would like to thank Mrs María Luisa Ragout who isolated and tentatively identified the new strain. We would also like to thank all the depositors of the strains used in this study.

\section{References}

Collins, M. D., Williams, A. M. \& Wallbanks, S. (1990). The phylogeny of Aerococcus and Pediococcus as determined by $16 \mathrm{~S}$ rRNA sequence analysis: description of Tetragenococcus gen. nov. FEMS Microbiol Lett 58, 255-262.

Collins, M. D., Rodrigues, U., Ash, C., Aguirre, M., Farrow, J. A. E., Martinez-Murcia, A., Phillips, B. A., Williams, A. M. \& Wallbanks, S. (1991). Phylogenetic analysis of the genus Lactobacillus and related lactic acid bacteria as determined by reverse transcriptase sequencing of 16S rRNA. FEMS Microbiol Lett 77, 5-12.

De Bruyne, K., Schillinger, U., Caroline, L., Böhringer, B., Cleenwerck, I., Vancanneyt, M., De Vuyst, L., Franz, C. M. A. P. \& Vandamme, P. (2007). Leuconostoc holzapfelii sp. nov., isolated from Ethiopian coffee fermentation and assessment of sequence analysis of housekeeping genes for delineation of Leuconostoc species. Int J Syst Evol Microbiol 57, 2952-2959.

De Ley, J., Cattoir, H. \& Reynaerts, A. (1970). The quantitative measurement of DNA hybridization from renaturation rates. Eur $J$ Biochem 12, 133-142.

Dobson, C. M., Deneer, H., Lee, S., Hemmingsen, S., Glaze, S. \& Ziola, B. (2002). Phylogenetic analysis of the genus Pediococcus, including Pediococcus claussenii sp. nov., a novel lactic acid bacterium isolated from beer. Int J Syst Evol Microbiol 52, 2003-2010. 
Franz, C. M. A. P., Vancanneyt, M., Vandemeulebroecke, K., De Wachter, M., Cleenwerck, I., Hoste, B., Schillinger, U., Holzapfel, W. H. \& Swings, J. (2006). Pediococcus stilesii sp. nov., isolated from maize grains. Int J Syst Evol Microbiol 56, 329-333.

Garvie, E. I. (1974). Nomenclatural problems of the pediococci. Request for an Opinion. Int J Syst Bacteriol 24, 301-306.

Garvie, E. I. (1986). Genus Pediococcus Claussen 1903, 68 ${ }^{\mathrm{AL}}$. In Bergey's Manual of Systematic Bacteriology, pp. 1075-1079. Edited by P. H. A. Sneath, N. S. Mair, M. E. Sharpe \& J. G. Holt. Baltimore: Williams \& Wilkins.

Holzapfel, W. H., Franz, C. M. A. P., Ludwig, W., Back, W. \& Dicks, L. M. T. (2005). Genera Pediococcus and Tetragenococcus. In The Prokaryotes, 3rd edn. An Evolving Electronic Resource for the Microbiological Community, release 3.15. Edited by M. Dworkin, S. Falkow, E. Rosenberg, K.-H. Schleifer \& E. Stackebrandt. New York: Springer-Verlag.

Konstantinidis, K. T., Ramette, A. \& Tiedje, J. M. (2006). Towards a more robust assessment of intra-species diversity using fewer genetic markers. Appl Environ Microbiol 72, 7286-7293.

Leroy, F. \& De Vuyst, L. (2004). Lactic acid bacteria as functional starter cultures for the food fermentation industry. Trends Food Sci Technol 15, 67-78.

Liu, L., Zhang, B., Tong, H. \& Dong, X. (2006). Pediococcus ethanolidurans sp. nov., isolated from the walls of a distilled-spiritfermenting cellar. Int J Syst Evol Microbiol 56, 2405-2408.

Marmur, J. (1961). A procedure for the isolation of deoxyribonucleic acid from microorganisms. J Mol Biol 3, 208-218.

Mesbah, M., Premachandran, U. \& Whitman, W. B. (1989). Precise measurement of the $\mathrm{G}+\mathrm{C}$ content of deoxyribonucleic acid by highperformance liquid chromatography. Int J Syst Bacteriol 39, 159-167.

Naser, S., Thompson, F. L., Hoste, B., Gevers, D., Vandemeulebroecke, K., Cleenwerck, I., Thompson, C. C., Vancanneyt, M. \& Swings, J. (2005a). Phylogeny and identification of Enterococci by atpA gene sequence analysis. J Clin Microbiol 43, 2224-2230.

Naser, S. M., Thompson, F. L., Hoste, B., Gevers, D., Dawyndt, P., Vancanneyt, M. \& Swings, J. (2005b). Application of multilocus sequence analysis (MLSA) for rapid identification of Enterococcus species based on rpoA and pheS genes. Microbiology 151, 2141-2150.

Naser, S. M., Dawyndt, P. S. R., Hoste, B., Gevers, D., Vandemeulebroecke, K., Cleenwerck, I., Vancanneyt, M. \& Swings, J. (2007). Identification of lactobacilli by pheS and rpoA gene sequence analyses. Int J Syst Evol Microbiol 57, 2777-2789.
Pot, B., Vandamme, P. \& Kersters, K. (1994). Analysis of electrophoretic whole-organism protein fingerprints. In Chemical Methods in Prokaryotic Systematics, pp. 493-521. Edited by M. Goodfellow \& A. G. O'Donnell. Chichester, UK: Wiley.

Renouf, V., Claisse, O. \& Lonvaud-Funel, A. (2007). Inventory and monitoring of wine microbial consortia. Appl Microbiol Biotechnol 75, 149-164.

Sakamoto, K. \& Konings, W. N. (2003). Beer spoilage bacteria and hop resistance. Int J Food Microbiol 89, 105-124.

Schillinger, U. \& Lücke, F.-K. (1987). Identification of lactobacilli from meat and meat products. Food Microbiol 4, 199-208.

Simpson, W. J. \& Taguchi, H. (1995). The genus Pediococcus, with notes on the genera Tetragenococcus and Aerococcus. In The Genera of Lactic Acid Bacteria, pp. 125-172. Edited by B. J. B. Wood \& W. H. Holzapfel. Blackie Academic \& Professional.

Sneath, P. H. A., Mair, N. S., Sharpe, M. E. \& Holt, J. G. (1986). Bergey's Manual of Systematic Bacteriology. Edited by J. P. Butler. Baltimore, USA: Williams \& Wilkins.

Stackebrandt, E. \& Kandler, O. (1979). Taxonomy of the genus Cellulomonas, based on phenotypic characters and deoxyribonucleic acid-deoxyribonucleic acid homology and proposal of seven neotype strains. Int J Syst Bacteriol 29, 273-282.

Stiles, M. E. \& Holzapfel, W. H. (1997). Lactic acid bacteria of foods and their current taxonomy. Int J Food Microbiol 36, 1-29.

Tanasupawat, S., Pakdeeto, A., Thawai, C., Yukphan, P. \& Okada, S. (2007). Identification of lactic acid bacteria from fermented tea leaves (miang) in Thailand and proposals of Lactobacillus thailandensis sp. nov., Lactobacillus camelliae sp. nov., and Pediococcus siamensis sp. nov. J Gen Appl Microbiol 53, 7-15.

Vancanneyt, M., Mengaud, J., Cleenwerck, I., Hoste, B., Dawyndt, P., Degivry, M. C., Ringuet, D., Janssens, D. \& Swings, J. (2004). Reclassification of Lactobacillus kefirgranum Takizawa et al. 1994 as Lactobacillus kefiranofaciens subsp. kefirgranum subsp. nov. and emended description of L. kefiranofaciens Fujisawa et al. 1988. Int J Syst Evol Microbiol 54, 551-556.

Wayne, L. G., Brenner, D. J., Colwell, R. R., Grimont, P. A. D., Kandler, O., Krichevsky, M. I., Moore, L. H., Moore, W. E. C., Murray, R. G. E. \& other authors (1987). International Committee on Systematic Bacteriology. Report of the ad hoc committee on reconciliation of approaches to bacterial systematics. Int J Syst Bacteriol 37, 463-464.

Zhang, B., Tong, H. \& Dong, X. (2005). Pediococcus cellicola sp. nov., a novel lactic acid coccus isolated from a distilled-spirit-fermenting cellar. Int J Syst Evol Microbiol 55, 2167-2170. 